\title{
PENGARUH LINGKUNGAN KELAS TERHADAP SIKAP SISWA UNTUK PELAJARAN MATEMATIKA
}

\author{
Joice Novita Limpo, Hasan Oetomo, dan Maria Helena Suprapto \\ Fakultas Psikologi, Universitas Pelita Harapan Surabaya \\ Jl. Ahmad Yani No.228 Surabaya 60234 \\ oker11394@gmail.com/h_oetomo@yahoo.com/ \\ helena.suprapto@uphsurabaya.ac.id
}

\begin{abstract}
Abstrak
Attitude plays a great role in student's learning behavior. This study was designed to investigate the contributions of classroom environment to students' attitude toward math. Participants in this study were 70 students of Etika Dharma Catholic Junior High School in Surabaya. Classroom environment was measured using adaptation of what is happening in This Class? (WIHIC) scale and attitude toward math was measured using a scale developed by the researcher. The result shows that there is a significant positive correlation between classroom environment and attitude toward math $(\mathrm{r}=0,359, \mathrm{p}<0,01)$, which means the more positive students' perception of their classroom environment, the more positive their attitude towards math would be. The linear regression analysis shows that classroom environment effectively contributes $12,9 \%$ to students' attitude toward math $\left(r^{2}=0,129\right)$. Classroom environment can be used to predict students' attitude toward math, with the equation $Y=48,916+0,229 \mathrm{X} \pm 23,023$. Result shows that classroom environment has a significant influence on attitude toward math, although not too significant. This is due to the existence of other variables that may influence attitude toward math, such as achievement, peers, teacher, and other environmental factors.
\end{abstract}

Keywords: attitude toward math, classroom environment, math

\begin{abstract}
Abstrak
Sikap adalah unsur penting dalam mendukung perilaku belajar siswa.Penelitian ini bertujuan untuk mengetahui apakah ada pengaruh lingkungan kelas terhadap sikap siswa terhadap matematika. Partisipan penelitian adalah 70 siswa SMPK Pekerti, Surabaya. Lingkungan kelas diukur menggunakan adaptasi skala What is Happening in This Class?
\end{abstract}


(WIHIC) dan sikap siswa diukur menggunakan Skala Sikap Siswa terhadap Matematika yang dibuat oleh peneliti. Hasil uji korelasi menunjukkan ada hubungan positif yang signifikan antara lingkungan kelas dengan sikap siswa terhadap matematika $(r=0,359, \mathrm{p}<0,01)$, yang berarti semakin positif persepsi siswa terhadap lingkungan kelas, semakin positif sikap siswa terhadap matematika. Selain itu, model regresi menunjukkan bahwa lingkungan kelas memberikan sumbangan efektif sebesar 12,9\% terhadap sikap siswa terhadap matematika $\left(R^{2}=0,129\right)$. Lingkungan kelas dapat digunakan untuk memprediksi sikap siswa terhadap matematika, dengan persamaan regresi $Y=48,916+0,229 X \pm 23,023$. Hasil penelitian menunjukkan lingkungan kelas memiliki pengaruh yang signifikan terhadap sikap siswa terhadap matematika, meskipun tidak besar. Hal ini karena adanya variabel lain yang mempengaruhi sikap terhadap matematika selain lingkungan kelas, seperti: prestasi, faktor guru, teman sebaya, dan faktor lainnya.

Kata kunci: lingkungan kelas, matematika, sikap terhadap matematika,

\section{Pendahuluan}

Salah satu mata pelajaran yang 'populer' sebagai pelajaran yang kurang disukai adalah matematika. Mitos tersebutlah yang ikut mendorong masyarakat mengadopsi pandangan yang negatif terhadap matematika (Hanafi, 2011). Pandangan negatif ini pun tampaknya berlaku di Indonesia, yang tergambar dalam beberapa artikel berita, yang salah satunya dengan kreatif menganalogikan matematika dengan obat pahit, sesuatu yang dibenci tetapi harus ditelan (Nasution, 2011), sementara artikel lain mengiaskan matematika sebagai hantu, sesuatu yang harus dibenci, ditakuti, dan dihindari (Hanafi, 2011). Matematika merupakan pelajaran yang penting, terutama karena matematika dapat digunakan dalam kehidupan sehari-hari untuk menyelesaikan masalah (Bishop, dalam Mohamed \& Waheed, 2011). Akan tetapi, siswa justru kurang menyukai mata pelajaran yang penting ini.

Sikap siswa terhadap matematika yang cenderung negatif ini merupakan hal yang penting dan perlu diperhatikan. Sikap siswa terhadap matematika dapat didefinisikan sebagai kecenderungan yang dipelajari individu untuk merespon secara positif atau negatif terhadap matematika (Aiken, dalam Bassette, 2004). Sikap dapat ditinjau melalui 3 dimensi, yaitu dimensi kognitif, afektif, dan konatif. Dimensi kognitif 
adalah pikiran dan kepercayaan yang dihubungkan dengan matematika. Dimensi afektif adalah perasaan yang dihubungkan dengan matematika. Dimensi konatif mencakup kecenderungan seseorang untuk melakukan hal-hal yang berhubungan dengan matematika.

Mager (Rivera \& Ganaden, 2001) mengungkapkan tiga alasan mengapa sikap siswa terhadap suatu mata pelajaran perlu ditingkatkan. Pertama, sikap siswa terhadap mata pelajaran nampaknya berhubungan dengan prestasinya dalam mata pelajaran tersebut. Kedua, siswa dengan sikap positif terhadap matematika kemungkinan besar akan memiliki insiatif untuk memperdalam pengetahuan dan pembelajarannya mengenai matematika. Ketiga, sikap seringkali dikomunikasikan kepada teman sebaya dengan berbagai cara selama kehidupan. Karena besarnya peranan sikap dalam pembelajaran siswa, banyak penelitian dilakukan untuk mengetahui faktor yang mempengaruhinya, seperti faktor individual (Tocci \& Engelhard, 1991) dan faktor lingkungan (Ramirez, 2005).

Salah satu faktor lingkungan yang mungkin mempengaruhi adalah lingkungan kelas. Lingkungan kelas adalah lingkungan yang dekat dan dapat berpengaruh langsung pada individu (Bronfrenbenner, dalam Santrock, 2011). Namun, peranan lingkungan kelas masih kurang diteliti di Indonesia (Tarmidi, 2006). Penelitian sebelumnya mengenai lingkungan kelas lebih berfokus kepada hubungan antara lingkungan kelas dengan motivasi belajar (Hadinata, 2009), prestasi belajar (Tarmidi, 2006), serta kreativitas (Sagala, 2010). Sampai saat ini, penulis belum menjumpai penelitian yang berfokus pada pengaruh lingkungan kelas terhadap sikap siswa. Oleh karena itu, penulis memutuskan untuk meneliti tentang peranan lingkungan kelas terhadap sikap siswa untuk pelajaran matematika.

Ezeife dan Smith (2010) mendefinisikan lingkungan kelas sebagai atmosfir, suasana, atau iklim yang terdapat dalam kelas selama proses belajar mengajar. Suasana ini merupakan hasil dari interaksi guru dan siswa, serta interaksi antarsiswa (Scmhuck \& Scmhuck, dalam Zedan, 2010). Moos (dalam Baek \& Choi, 2002) menambahkan bahwa lingkungan kelas seperti halnya kepribadian pada manusia, dapat memiliki kualitas yang berbeda, seperti kehangatan dan dukungan ataupun kekakuan dan ketegasan. Dengan kata lain, masing-masing kelas memiliki lingkungan yang berbeda-beda dan unik, meskipun dibangun dalam struktur dan arsitektur yang sama.

Moos (Dorman, 1999) membagi lingkungan kelas ke dalam 3 dimensi, yaitu dimensi hubungan, dimensi pertumbuhan pribadi, dan dimensi pemeliharaan dan perubahan sistem. Dimensi hubungan mencakup hubungan interpersonal antarsiswa, 
ataupun guru dan siswa, serta sejauh mana keterlibatan siswa dalam kelas. Dimensi pertumbuhan pribadi mencakup perkembangan kepribadian dan kemampuan yang dapat terjadi dalam suatu lingkungan. Dimensi pemeliharaan dan perubahan sistem mencakup keteraturan dalam lingkungan.

Ketiga dimensi yang dikemukakan Moos (dalam Dorman, 1999) ini kemudian dikembangkan menjadi 7 indikator oleh Fraser (1998). Fraser (1998) mengembangkan dimensi hubungan menjadi 3 indikator, yaitu kohesivitas siswa, dukungan guru, dan keterlibatan. Kohesivitas siswa adalah taraf sejauh mana siswa saling mengenal, mendukung, dan mau membantu satu sama lain. Selain kohesivitas siswa, dukungan guru terhadap siswa, serta keterlibatan siswa dalam aktivitas kelas pun diukur dalam dimensi ini.

Fraser (1998) juga mengembangkan dimensi pertumbuhan pribadi menjadi 3 indikator, yaitu investigasi, orientasi tugas, dan kerja sama. Indikator investigasi merujuk pada kemampuan siswa untuk meneliti dan mengembangkan konsep pengetahuannya secara mandiri. Orientasi tugas merujuk pada seberapa penting penyelesaian kegiatan yang direncanakan dan tetap berpatokan pada topik yang dipelajari. Indikator kerja sama mengukur sejauh mana siswa saling bekerja sama, dan bukannya bersaing dalam proses pembelajaran. Fraser (1998) mengukur dimensi pemeliharaan dan perubahan sistem menggunakan 1 indikator, yaitu kesetaraan. Indikator ini merujuk pada taraf sejauh mana siswa diperlakukan setara oleh guru.

Dalam situasi lingkungan kelas, banyak kesempatan terjadinya berbagai interaksi dan pengalaman yang dapat membentuk sikap siswa terhadap berbagai hal, seperti sikap terhadap sekolah (Cheng, 1994), sikap terhadap teman sebaya (Cheng, 1994), dan sikap terhadap subjek yang tengah dipelajari. Selama proses belajar mengajar, berbagai hal yang terjadi dalam lingkungan kelas, seperti perlakuan guru terhadap siswa ataupun hubungan antarsiswa, dapat menimbulkan perasaan atau pemikiran tertentu di benak siswa. Perasaan dan kurangnya pemikiran ini, baik positif maupun negatif, ketika terjadi berulang kali akan kemudian diasosiasikan dengan mata pelajaran itu sendiri. Melalui proses asosiasi tersebut, sikap terhadap suatu mata pelajaran dapat dibentuk. Oleh karena itu, penulis tertarik untuk meneliti adanya pengaruh lingkungan kelas memiliki terhadap sikap siswa terhadap matematika. Penelitian ini unik karena penelitian ini dapat menjawab pertanyaan penting mengenai ada atau tidaknya pengaruh lingkungan kelas terhadap sikap siswa terhadap matematika, sebagai mata pelajaran yang kurang disukai di Indonesia. 


\section{Metode Penelitian}

Penelitian dilakukan di sebuah sekolah menengah swasta, di Surabaya, yang melibatkan seluruh siswa yang berjumlah 76 orang. Pengambilan sampel dilakukan menggunakan teknik total population sampling, dengan pertimbangan jumlah populasi yang sedikit. Data yang dikumpulkan berjumlah 72, sesuai dengan jumlah siswa yang hadir. Namun, dua kuisioner tidak layak pakai karena subjek tidak menjawab atau melompati beberapa aitem sekaligus. Penelitian dilakukan menggunakan data dari 70 siswa, yang terdiri dari 36 laki-laki dan 34 perempuan.

Pengumpulan data dilakukan dengan pembagian skala. Penelitian ini menggunakan pendekatan uji coba terpakai, yaitu pengumpulan data untuk kepentingan uji coba alat ukur, sekaligus uji hipotesis.

Variabel independen dalam penelitian ini adalah lingkungan kelas. Lingkungan kelas diukur menggunakan adaptasi dari skala What is Happening in This Class (WIHIC) yang dikembangkan oleh Fraser (1998) dan diterjemahkan ke dalam bahasa Indonesia oleh Margianti (2002). Skala ini dikembangkan berdasarkan 7 indikator lingkungan kelas dan terdiri dari 56 aitem. Skala ini memiliki reliabilitas dengan nilai Alpha Cronbach sebesar 0,951 setelah menggugurkan tiga aitem. Contoh aitem untuk tiap indikator dari adaptasi skala WIHIC dapat dilihat pada Tabel 1.

Tabel 1

Contoh Aitem Adaptasi Skala Wihic Berdasarkan Indikator

\begin{tabular}{|c|c|}
\hline Indikator & Contoh aitem \\
\hline Kohesivitas siswa & Saya bersahabat dengan semua siswa di kelas ini. \\
\hline Dukungan guru & Guru memperhatikan saya dengan cermat. \\
\hline Keterlibatan & $\begin{array}{l}\text { Saya memberikan pendapat saya selama diskusi di kelas } \\
\text { berlangsung. }\end{array}$ \\
\hline Investigasi & $\begin{array}{l}\text { Saya diminta untuk memikirkan bukti yang mendukung } \\
\text { suatu pernyataan. }\end{array}$ \\
\hline Orientasi tugas & Saya tahu apa yang harus saya capai dalam pelajaran ini. \\
\hline Kerja sama & $\begin{array}{l}\text { Saya bekerja sama dengan siswa lainnya dalam } \\
\text { mengerjakan proyek di kelas ini. }\end{array}$ \\
\hline Kesetaraan & $\begin{array}{l}\text { Saya mendapat kesempatan yang sama untuk menjawab } \\
\text { pertanyaan seperti siswa lainnya. }\end{array}$ \\
\hline
\end{tabular}


Variabel tergantung dalam penelitian ini adalah sikap siswa terhadap matematika. Sikap siswa terhadap matematika diukur menggunakan skala yang dikembangkan oleh peneliti berdasarkan 4 indikator yang dikembangkan oleh Neale (dalam Stramel, 2010), yaitu 1) keyakinan bahwa matematika itu berguna atau tidak; (2) keyakinan bahwa seseorang cakap atau tidak dalam matematika; (3) kesukaan atau ketidaksukaan terhadap matematika; dan (4) kecenderungan untuk mengikuti atau menghindari aktivitas matematika. Skala ini terdiri dari 32 aitem, yaitu 8 aitem untuk masing-masing indikator. Skala ini memiliki reliabilitas dengan nilai Alpha Cronbach sebesar 0,929 setelah menggugurkan empat aitem. Contoh aitem untuk tiap indikator dari adaptasi skala sikap siswa terhadap matematika dapat dilihat pada Tabel 2.

Tabel 2

Aitem dalam Setiap Indikator pada Skala Sikap Terhadap Matematika

\begin{tabular}{ll}
\hline \multicolumn{1}{c}{ Indikator } & \multicolumn{1}{c}{ Contoh aitem } \\
\hline Kepercayaan tentang matematika & $\begin{array}{l}\text { Belajar matematika akan berguna dalam } \\
\text { bidang pekerjaan yang ingin saya tekuni kelak } \\
\text { Saya dapat dengan mudah menyelesaikan }\end{array}$ \\
$\begin{array}{l}\text { Kepercayaan diri dalam } \\
\text { matematika }\end{array}$ & $\begin{array}{l}\text { soal matematika. } \\
\text { Kesenangan belajar matematika }\end{array}$ \\
$\begin{array}{l}\text { Salah satu hobi saya adalah mengerjakan } \\
\text { Soal matematika dan mengutak-atik angka. }\end{array}$ \\
$\begin{array}{l}\text { Kecenderungan melakukan hal } \\
\text { matematika }\end{array}$ & $\begin{array}{l}\text { Saya merasa tertantang untuk mengerjakan } \\
\text { soal matematika yang sulit. }\end{array}$ \\
\hline
\end{tabular}

\section{Hasil dan Pembahasan}

Peneliti melakukan uji asumsi yang terdiri dari uji normalitas dan uji linearitas pada data yang telah terkumpul. Hasil uji normalitas Kolmogorov-Smirnov menunjukkan nilai signifikansi Kolmogorov-Smirnov sebesar 0,200 (p> 0,05). Hal ini menunjukan bahwa data variabel lingkungan kelas dan variabel sikap siswa terhadap matematika mengikuti sebaran normal. Uji linearitas lalu dilakukan dengan membentuk grafik scatterplot. Hasil uji linearitas menunjukkan bahwa sebaran nilai variabel lingkungan kelas dan variabel sikap siswa terhadap matematika mengikuti garis linier. Oleh karena data telah terbukti normal dan linear, maka pengujian hipotesis dengan menggunakan uji regresi dapat dilakukan. 
Uji regresi menunjukkan adanya korelasi antara variabel lingkungan kelas dan sikap siswa terhadap matematika dengan koefisien sebesar $r=0,359$ dengan $p=0,001$ ( $\mathrm{p}<0,01 ; a ́=0,01$ ). Nilai $\mathrm{r}$ menunjukkan adanya korelasi positif antara lingkungan kelas dan sikap siswa terhadap matematika. Hal ini berarti semakin tinggi persepsi siswa terhadap lingkungan kelas Matematika, semakin positif pula sikap siswa terhadap matematika.

Hasil analisis regresi menunjukkan nilai $\mathrm{R}^{2}=0,129$. Angka ini menunjukkan bahwa 12,9\% dari sikap siswa terhadap matematika dapat dijelaskan oleh variabel lingkungan kelas, sementara 87,1\% dapat dijelaskan oleh variabel lain. Model regresi dinyatakan signifikan, dengan $\mathrm{F}=10,051, \mathrm{p}=0,002$ ( $\mathrm{p}<0,01)$. Hal ini menunjukkan bahwa model regresi dapat dipakai untuk memprediksi sikap siswa terhadap matematika. Untuk mengetahui persamaan garis regresi, koefisien persamaan dapat dilihat pada Tabel 3 .

Tabel 3

Koefisien Persamaan Garis Regresi

\begin{tabular}{llllll}
\hline Model & B & Std. Error & Beta & t & $\boldsymbol{p}$ \\
\hline (Constant) & 48.916 & 14.387 & & 3.400 & .001 \\
Lingkungan Kelas.229 & .072 & .359 & 3.170 & .002 \\
\hline
\end{tabular}

Koefisien persamaan regresi yang digunakan adalah koefisien tidak terstandar. Persamaan regresi yang diperoleh adalah:

$$
\mathrm{Y}=48,916+0,229 \mathrm{X} \pm 23,023
$$

Y adalah nilai variabel terikat, atau sikap siswa terhadap matematika, dan X adalah nilai variabel bebas, yaitu lingkungan kelas. Persamaan ini berarti bahwa setiap penambahan satu nilai lingkungan kelas turut menambah nilai sikap terhadap matematika sebesar 0,229 dengan estimasi kesalahan sebesar 23,023.

Hasil uji hipotesis menunjukkan adanya pengaruh lingkungan kelas terhadap sikap siswa terhadap matematika. Kedua variabel memiliki korelasi positif $(\mathrm{r}=0,359$, $\mathrm{p}<0,01$ ), yang menunjukkan bahwa semakin positif persepsi siswa terhadap lingkungan kelas, semakin positif pula sikap siswa terhadap matematika.

Lingkungan kelas adalah salah satu lingkungan terdekat yang dimiliki oleh individu yang bersekolah di SMP, yang masih tergolong remaja awal (Papalia, 
Olds, \& Feldman, 2006). Hal ini berarti bahwa lingkungan kelas adalah salah satu faktor yang dapat mempengaruhi perilaku dan karakteristik pribadi siswa. Sikap terhadap matematika adalah salah satu karakteristik pribadi yang dipengaruhi oleh lingkungan kelas, terutama karena interaksi siswa dengan matematika sebagian besar terjadi di dalam kelas. Hasil penelitian ini memperkuat penelitian terdahulu yang juga melaporkan adanya pengaruh lingkungan kelas terhadap sikap siswa terhadap matematika (Goh \& Fraser, 1998; Ogbuehi \& Fraser, 2007).

Hasil uji regresi menunjukkan bahwa 12,9\% dari sikap siswa terhadap matematika dapat dijelaskan oleh variabel lingkungan kelas, sedangkan 87,1\% dijelaskan oleh variabel lain. Hasil ini menunjukkan adanya pengaruh lingkungan kelas terhadap sikap terhadap matematika meskipun tidak terlalu besar. Hal ini sesuai dengan pernyataan Mohammed dan Waheed (2011) yang menjelaskan bahwa sikap terhadap matematika bukan hanya dipengaruhi oleh faktor lingkungan kelas, tetapi juga dipengaruhi oleh karakteristik siswa dan faktor lingkungan yang lain.

Hasil penelitian menunjukkan bahwa lingkungan kelas memberikan sumbangan efektif sebesar $12,9 \%$ pada sikap siswa terhadap matematika. Meskipun lingkungan kelas memberikan sumbangan efektif yang tidak terlalu besar terhadap sikap siswa terhadap matematika, pengaruh lingkungan kelas telah terbukti signifikan. Hasil ini menunjukkan bahwa sikap terhadap matematika yang lebih positif ditunjukkan oleh siswa ketika persepsi mereka terhadap lingkungan kelas juga positif. Sikap siswa terhadap matematika dapat ditingkatkan dengan cara membina lingkungan kelas yang kondusif, khususnya pada tujuh aspek lingkungan kelas, yaitu: kohesivitas siswa, dukungan guru, keterlibatan, investigasi, orientasi tugas, kerja sama, dan kesetaraan.

Variabel lain yang dapat menjelaskan sikap siswa terhadap matematika adalah pencapaian siswa dalam pelajaran matematika. Prestasi matematika siswa telah terbukti memiliki hubungan positif dengan sikap siswa terhadap matematika (Tocci \& Engelhard, 1991). Semakin tinggi prestasi siswa di dalam pelajaran matematika, maka semakin positif sikap siswa tersebut terhadap pelajaran matematika. Hal ini dikarenakan prestasi merupakan salah satu pengalaman langsung dengan objek sikap, atau matematika. Melalui pengalaman langsung ini, informasi yang diperoleh mengenai objek sikap dapat mempengaruhi sistem kognitif, afektif, dan konatif siswa.

Faktor lain yang juga dapat menjelaskan sikap siswa terhadap matematika adalah sikap orang lain yang dianggap penting oleh individu terhadap matematika. Orang lain yang dianggap penting bisa merupakan orangtua, guru, ataupun teman 
sebaya. Individu akan cenderung membentuk sikap yang searah dengan sikap orang lain tersebut agar dapat berafiliasi ataupun menghindari konflik dengan orang yang dianggap penting (Azwar, 1995). Rendahnya sikap subjek penelitian terhadap matematika dapat dipengaruhi oleh faktor ini. Sikap teman kelas yang negatif terhadap matematika dapat mempengaruhi sikap individu lain ke arah yang sama.

Hasil penelitian ini menyatakan pentingnya peran guru, sebagai figur yang dapat memanipulasi langsung lingkungan kelas, untuk membentuk lingkungan kelas yang dapat meningkatkan sikap siswa terhadap objek pembelajaran. Seorang guru dapat membentuk lingkungan dan merancang kegiatan pembelajaran yang dapat meningkatkan kohesivitas siswa, kerja sama, serta keterlibatan siswa. Kegiatan yang disiapkan juga dapat berupa kegiatan mandiri, untuk meningkatkan kemampuan investigasi siswa, serta memberikan batas waktu yang jelas sehingga dapat meningkatkan orientasi siswa terhadap tugas. Ketika pembelajaran berlangsung, guru dapat berpartisipasi aktif dengan memberikan dukungan yang cukup serta memberikan perlakuan yang setara bagi seluruh siswa. Lingkungan kelas yang mempromosikan ketujuh aspek tersebut akan menjadi suatu pengalaman positif bagi siswa. Apabila lingkungan kelas yang diciptakan oleh guru bersifat konsisten, maka siswa akan belajar untuk membentuk sikap positif terhadap kegiatan belajar dan terhadap mata pelajaran yang diajarkan.

\section{Simpulan}

Hubungan antara lingkungan kelas dan sikap siswa adalah positif $(\mathrm{r}=0,359$, $\mathrm{p}<0,01$ ), yaitu semakin positif sikap siswa terhadap lingkungan kelas, maka semakin positif pula sikap siswa terhadap matematika, begitu pula sebaliknya. Meskipun pengaruh lingkungan kelas terhadap sikap siswa terhadap matematika adalah signifikan. Namun, pengaruh yang dimiliki tidak terlalu besar $\left(R^{2}=0,129\right)$. Hal ini berarti sikap siswa terhadap matematika juga dipengaruhi oleh variabel selain lingkungan kelas, seperti prestasi matematika siswa dan sikap orang lain terhadap matematika.

\section{Daftar Pustaka}

Azwar, S. (1995). Sikap Manusia: Teori dan Pengukurannya. Yogyakarta: Pustaka Pelajar. 
Baek, S.G \& Choi, H.J. (2002). The relationship between students' perceptions of classroom environment and their academic achievement in Korea. Asia Pacific Education Review, 3(1), 125-135.

Bassette, L. P. (2004). An assessment of the attitudes and outcomes of students enrolled in developmental basic mathematics classes at Prince George's community college (Doctoral dissertation). Virginia Polytechnic Institute and State University.. Diunduh dari http:// academia.edu/

Cheng, Y. C. (1994). Classroom environment and student affective performance: An effective profile. The Journal of Experimental Education, 62 (3), 221239.

Dorman, J. P. (1999). The evolution, validation, and use of a personal form of the Catholic School Classroom Environment Questionnaire. Catholic Education: A Journal of Inquiry and Practice, 3(2), 141-157.

Ezeife, A. N. \& Smith, C. B. (2010). The relationship between students' perceptions of their classroom environment and their attitudes toward science in grade nine applied science classes. Academic Exchange EXTRA. Diunduh dari http://www.unco.edu/AEExtra/2010/4/ ezeife.html

Fraser, B. J. (1998). Classroom environment instruments: Development, validity, and applications. Learning Environments Research, 1, 7-33.

Goh, S. C. \& Fraser, B. J. (1998). Teacher interpersonal behaviour, classroom environment and student outcomes in primary Mathematics in Singapore. Learning Environments Research, 1, 199-229.

Hadinata, P. (2009). Iklim kelas dan motivasi belajar siswa SMA. Jurnal Psikologi, 3(1), 93-98.

Hanafi, W. (6 April 2011). Hantu Matematika. Diunduh dari http://www.surya.co.id/ 2011/04/06/hantu-matematika.

Lewin, K. (1936). Principles of Topological Psychology. New York: McGraw.

Margianti, E. S. (2002). Learning environment research in Indonesia. In S. C. Goh \& M. S. Khine (Eds.), Studies in Educational Learning Environments: An International Perspective (p.153-168). Singapore: World Scientific Publishing Co. Pte. Ltd. 
Mohamed, L. \& Waheed, H. (2011). Secondary students' attitude towards Mathematics in a selected school of Maldives. International Journal of Humanities and Social Science, 1(15), 277-281.

Nasution (20 April 2011). Matematika: Seperti obat pahit, dibenci tapi harus ditelan. Diunduh tanggal 26 Agustus 2011, dari http:// sosbud.kompasiana.com/2011/04/20/matematika-seperti-obat-pahitdibenci-tapi-harus-ditelan/

Ogbuehi, P. I. \& Fraser, B. J. (2007). Learning environment, attitudes and conceptual development associated with innovative strategies in middle-school Mathematics. Learning Environments Research, 10, 101-114.

Papalia, D. E., Olds, S. W., \& Feldman, R. D. (2006). Human development (10 ${ }^{\text {th }}$ Ed). New York: McGraw Hill.

Ramirez, M. J. (2005). Attitudes toward mathematics and academic performance among Chilean $8^{\text {th }}$ graders. Estudios Pedagogicos, 1, 97-112.

Rivera, T. C. \& Ganaden, M. F. (2001). Classroom psychosocial environment. International Online Journal of Science and Mathematics Education, 1 . Diunduh dari http://www.upd.edu.ph/ ismed/online/articles/psycho/ psycho. htm

Sagala, C. (2010). Hubungan persepsi terhadap iklim kelas dengan kreativitas pada siswa SMA Kalam Kudus Medan (Skripsi, Universitas Sumatera Utara, 2010). Diunduh dari http://repository.usu.ac.id/bitstream/123456789/ 17377/ 6/Cover.pdf

Santrock, J. W. (2011). Educational Psychology (5 ${ }^{\text {th }}$ Edition), pp. 71-72. New York: McGraw Hill.

Stramel, J. (2010). A naturalistic inquiry into the attitudes toward mathematics and mathematics self-efficacy beliefs of middle school students (Doctoral dissertation, Kansas State University, 2004). Diunduh dari http://krex.kstate.edu/

Tarmidi. (2006). Iklim kelas dan prestasi belajar (Skripsi, Universitas Sumatera Utara, 2006). Diunduh dari http://repository.usu.ac.id/bitstream/123456789/ 1928/1/06010310.pdf

Tocci, C. M., \& Engelhard, G. (1991). Achievement, parental support and gender differences in attitudes towards mathematics. Journal of Educational Research, 84, 280-286. 
Zedan, R. (2010). New dimensions in classroom climate. Learning Environments Research, 13, 75-88. 